Alby, Sophie \& Isabelle Léglise. (2018). Multilingualism and translanguaging as a resource for teaching and learning in French Guiana. In : P. Van Avermaet, S. Slembrouck, K. Van Gorp, S. Sierens, K. Maryns, (eds.), The multilingual edge of education. Londres: Palgrave Macmillan, 115-137.

\title{
Multilingualism and translanguaging as a resource for teaching and learning in French Guiana $^{\mathrm{i}}$
}

\author{
Alby, Sophie - UMR 8202 SEDYL - ESPE Guyane (Université de Guyane) \\ Léglise, Isabelle - CNRS, UMR 8202 SEDYL
}

\section{Abstract}

The French educational system commonly invalidates the multilingualism of primary school children. Education in French Guiana, a French overseas territory, also operates under this system and therefore minority languages (Indigenous languages, Creole languages, Migrant languages and so on) are rarely or never taken into account in schools. Official texts do not prohibit the use of languages other than French in the classroom; however, education officials often state that other languages are prohibited when advising and evaluating teachers. However, ethnographic fieldwork and data from a range of schools in French Guiana show that in everyday interactions teachers do codeswitch and that children's mother tongues are often used in the classroom by the children (in some form of translanguaging), by the teachers, and by other participants. This paper shows that multilingualism and translanguaging can be a positive asset for both teaching and learning.

\section{Introduction}

In French Guiana, a French overseas territory, roughly two thirds of children do not speak French, the official language and the language of instruction, before going to school (Léglise, 2013), however many do speak several languages other than French. The French national educational system ideology is that monolingualism is seen as the norm in education. The discrepancy between children's home and school language and culture has long been 'perceived to be the root cause of the serious educational problems facing the region. French Guiana has the lowest rate of educational achievement in all of France and a high school dropout rate; nearly half of all the children leave school without any school diploma' (Migge and Léglise, 2010, p.111). This has led to academic critique ranging from anthropologists and linguists writing against 'non adapted schools' (Hurault, 1972; Grenand, 1982) to their partly successful activism for the introduction of local mother tongues into education (Launey, 1999; Goury et al., 2000). More recent studies in sociolinguistics and applied linguistics address other issues linked to language and education in French Guiana: they investigate teacher training (Alby and Launey, 2007), language policy in education (Alby and Léglise, 2005, 2014a), teachers' discourse on using children's mother tongues (Léglise and Puren, 2005; Alby and Léglise, 2014b) and teachers' language practice in the classrooms (Alby, 2008).

Some bilingual education programmes have been developed nationally or regionally over the last 20 years, but the officials and teachers in charge of them insist on language separation (different teachers, different moments, different spaces) as shown below. Education in French 
Alby, Sophie \& Isabelle Léglise. (2018). Multilingualism and translanguaging as a resource for teaching and learning in French Guiana. In : P. Van Avermaet, S. Slembrouck, K. Van Gorp, S. Sierens, K. Maryns, (eds.), The multilingual edge of education. Londres: Palgrave Macmillan, 115-137.

Guiana therefore depends on a national education system premised on a monolingual norm which largely disregards the multilingual reality of the school population. We would like to emphasize here that it is not only the discrepancy between home and school language which seems problematic, it is also the discrepancy between monolingual norms and monolingual thinking (ranging from linguistic assimilation towards French to language separation in the classroom and in the children's mind), and an everyday multilingual living experience.

In such a situation, even if language ideologies at the macro-level exert a powerful influence on the micro-level, it can be assumed that a tension will arise between institutional discourse and local practices. For even in a centralized education system such as the French one, teachers and students do have a certain amount of agency. Indeed, local responses sometimes show pragmatism and resilience to linguistic assimilation in action and language separation: in the classrooms where the studies presented below were carried out, students and also sometimes teachers use all their 'multilingual potential to maximize communication and learning' (García, 2009a). Despite the institutional monolingual norm, the multilingual reality of such children surfaces in everyday classroom interactions and in language learning. Nevertheless, analysis tends to strengthen the hypothesis of Creese and Blackledge (2010) that in practice the use of students' languages is primarily a pragmatic response to the local classroom context and that a lot still has to be done to move from codeswitching to translanguaging as a modus operandi (García, 2009a).

The aim of this paper is to examine the assumption of a gap between mainstream and dominant language ideology (both at a national and regional level) and local practice on the basis of studies which have been conducted in recent years in French Guiana. In order to understand this gap between different ways of speaking about and 'doing' codeswitching (a gap between discourse and practice), we will first present an overview of the political and institutional discourses with respect to language learning and codeswitching both at a national or macro level (through the analysis of legislation and curricula) and regional or meso level (through interviews of school officials ${ }^{\mathrm{ii}}$ ). Second, based on ethnographic observation and precise analysis of a substantial body of hours of (audio or video) recorded classroom interactions we will, at a micro level, discuss the discourse and practices of a number of teachers through the analysis of interviews and recording of classroom interactions. We show that teachers and students play a significant role in (re)constructing, negotiating and resisting top-down policies which reflect a monolingual ideology. Drawing on some 'good examples' from their own practices, we will then show that codeswitching, translanguaging and multilingualism in general can be valuable pedagogical resources for teaching and learning.

\section{Students' mother tongues and multilingual repertoire, an issue for education in French Guiana}

French Guiana is a French overseas territory like Martinique, Guadeloupe and La Réunion. It is located on the mainland of South America, bordering on Suriname and Brazil and has a 
Alby, Sophie \& Isabelle Léglise. (2018). Multilingualism and translanguaging as a resource for teaching and learning in French Guiana. In : P. Van Avermaet, S. Slembrouck, K. Van Gorp, S. Sierens, K. Maryns, (eds.), The multilingual edge of education. Londres: Palgrave Macmillan, 115-137.

population of approximately 250,000 inhabitants, 44 per cent of them under 20 . Educational performance is among the lowest in the French territories. Two thirds of primary schoolchildren and 80 per cent of students in secondary school come from disadvantaged families and receive what is called 'priority education" (education for children coming from deprived social sectors) (Pau-Langevin, 2014). A substantial majority of children (both French citizens and children of migrants) grow up without any contact with French which is the official and major language of education, and this has been linked to the poor school results. In this context, education is a real challenge and multilingualism is a major issue for social policy in general. Over 40 different languages are spoken in French Guiana, and 20 of these are spoken by at least 1 per cent (and for some languages by as much as 30 per cent) of the population, either as a mother tongue or as an additional language (Léglise, 2007). Moreover, these languages belong to different linguistic families. Table 1 provides an overview of these language families:

\begin{tabular}{|l|l|}
\hline Language types & Major Languages \\
\hline French-based Creoles & $\begin{array}{l}\text { Guianese Creole, Haitian Creole, Antillean Creole } \\
\text { (Martiniquan and Guadeloupean) }\end{array}$ \\
\hline English-based Creoles & $\begin{array}{l}\text { Eastern Maroon Creole (Ndyuka, Aluku, Pamaka), Sranan } \\
\text { Tongo }\end{array}$ \\
\hline $\begin{array}{l}\text { English-based Creoles } \\
\text { (relexified in Portuguese) }\end{array}$ & Saamaka \\
\hline $\begin{array}{l}\text { European languages (ex- } \\
\text { colonial languages in the } \\
\text { region) }\end{array}$ & French, Brazilian Portuguese, Dutch, English, Spanish \\
\hline Asian languages & Hmong, Hakka, Cantonese \\
\hline $\begin{array}{l}\text { Indigenous languages } \\
\text { Kali'na, Wayana and Apalai (Carib), Lokono and } \\
\text { Parikwaki (Arawak), Teko and Wayampi (Tupi-Guarani) }\end{array}$ \\
\hline
\end{tabular}

Table 1: Languages spoken by more than 1 per cent of the population

This linguistic diversity is reflected in the children's linguistic repertoire, as shown in Figure 1. This graph is the result of a survey conducted in all the primary schools in French Guiana (Léglise, 2007) and itshows the languages spoken by ten-year-old schoolchildren. The languages of initial socialization (spoken within the family before children begin school) are designated L1, those spoken or learned later are designated L2, L3, and so on. 


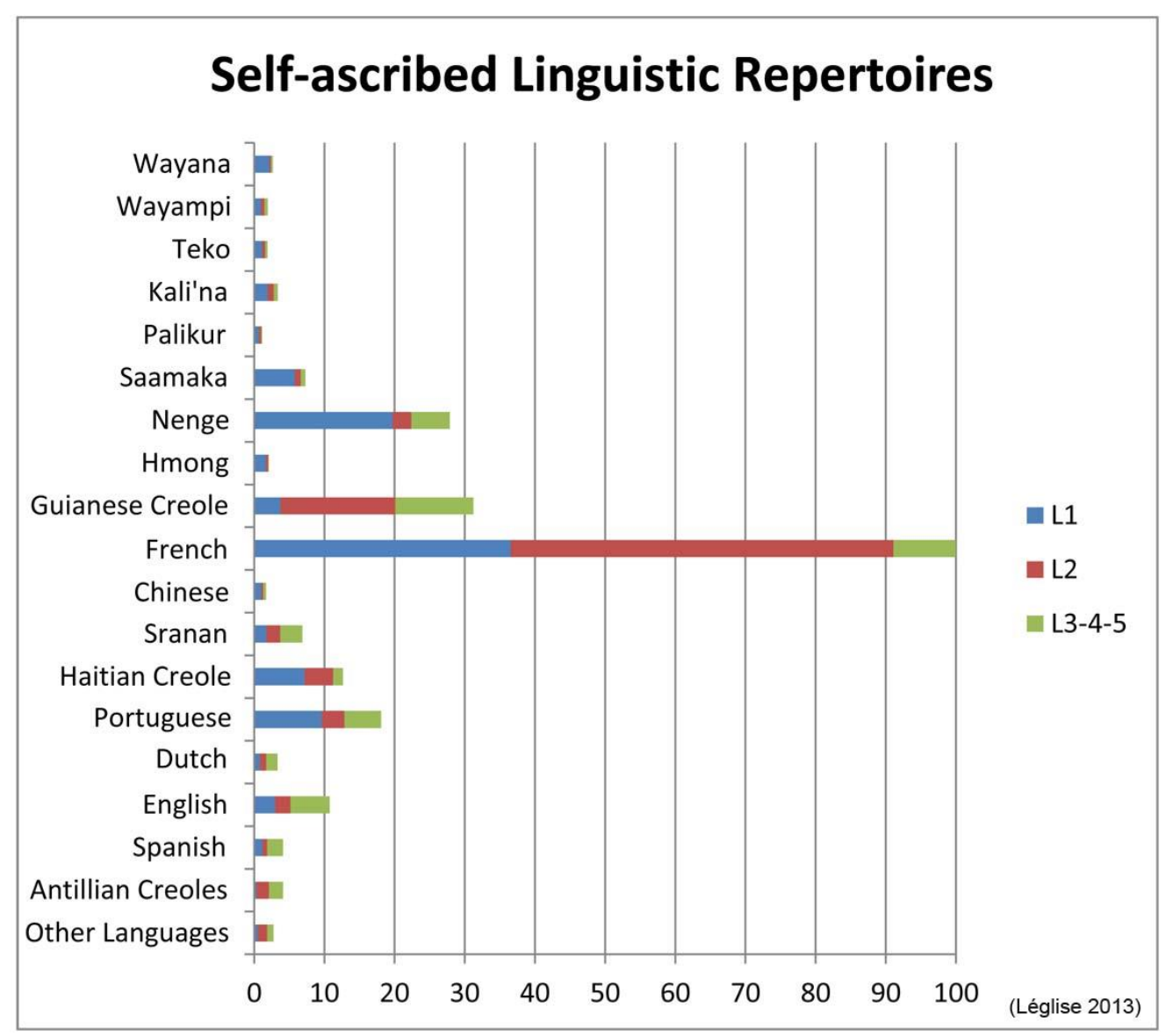

Figure 1: Languages in the children's repertoires and their status (Léglise, 2013)

Since French is the language of schooling, it appears in the repertoire of all schoolchildren, mostly as an L2. Five other languages have a significant presence: Nenge(e) Tongo (an English based Creole language, both as an L1 and as an additional language), Guianese Creole (mostly as an additional language, suggesting that most parents from Creole families choose to use French in the home and that children acquire the Creole in the playground or from elders), Brazilian Portuguese (both as an L1 and as an additional language) and Haitian Creole (mostly as an L1 but also as an additional language for those families who choose to use French or to align with Guianese Creole). The first four languages function as a lingua franca in some parts of French Guiana. However, language presence is not synonymous with official recognition: there is a gap between status and corpus. As the graph shows, only those languages listed above French on the graph are recognized as langues de France or langues régionales: these are considered to be 'local' languages, and this is mostly for historical reasons and because of the French citizenship of most of their speakers in French Guiana. They match the European definition of 'regional' languages, which defines "'regional or minority languages" as those: i. traditionally used within a given territory of a State by nationals of that State who form a group numerically smaller than the rest of the State's population; and ii. different from the official language(s) of that State (Conseil de l'Europe, 1992). This definition does not include the languages on the graph underneath French, either because these languages are recognized in other French territories (such as Antillean Creoles), 
Alby, Sophie \& Isabelle Léglise. (2018). Multilingualism and translanguaging as a resource for teaching and learning in French Guiana. In : P. Van Avermaet, S. Slembrouck, K. Van Gorp, S. Sierens, K. Maryns, (eds.), The multilingual edge of education. Londres: Palgrave Macmillan, 115-137.

or are considered to be 'migrant languages'. This distinction leads to inequities among children in school. As only officially recognised 'regional' or 'local' languages are ever used alongside French as the medium of instruction, some children benefit from the fact that their languages are recognized, even just for a few hours of class per week, while others do not. This educational model (which exists throughout the world) has the consequences noted by García and Kleifgen (2011: 167):

\begin{abstract}
Monolingual education, as carried out by the dominant language group in the state, plays an important role in ensuring that language minority communities do not receive a fair share of educational opportunities and that their bilingual resources and their multiple voices are diminished.
\end{abstract}

The question we address in the next section is therefore to ask how children's languages, and multilingualism in general, are taken into account in education both on the macro-level (the educational system and language policy), on a meso-level (in the discourse of school officials) and the micro-level (in classroom practices).

2. French Guiana: An example of the application of the assimilation policy of the French State

French policy tends to eschew all languages other than standard French in the public domain (Migge and Léglise, 2010). This policy is based on the idea that, since the Revolution, 'one nation equals one language'; as the second article of the French Constitution puts it: 'French is the language of the Republic.' iii There is no reference to minority languages in France, except for the new 75-1 Constitution article, which states that 'Regional languages are part of France's heritage'. Minority languages are thus theoretically neither excluded nor taken into account by the State. However, this gap in the Constitution amounts to an argument in favour of the exclusive use of French in all public institutions. In this context, language assimilation is seen as a civic ideal, as citizenship is strongly linked to the French language, and the recognition of France's own linguistic diversity is still controversial (for longer analysis, see Migge and Léglise 2013, chapter 2). French is the only medium of education in all the French territories, with a few exceptions presented in Table 2.

\begin{tabular}{|l|l|l|}
\hline Type of language & Educational model & Description \\
\hline \multirow{3}{*}{ (1) Foreign languages } & $\begin{array}{l}\text { (1a) Early learning activity in } \\
\text { primary school, foreign } \\
\text { language lessons in English, }\end{array}$ & $\begin{array}{l}\text { German, etc. at secondary } \\
\text { school. }\end{array}$ \\
\cline { 2 - 3 } & (1b) Capacity building & $\begin{array}{l}\text { 7 hours a week, plus teaching } \\
\text { of other school subjects } \\
\text { through the foreign language }\end{array}$ \\
\hline
\end{tabular}


Alby, Sophie \& Isabelle Léglise. (2018). Multilingualism and translanguaging as a resource for teaching and learning in French Guiana. In : P. Van Avermaet, S. Slembrouck, K. Van Gorp, S. Sierens, K. Maryns, (eds.), The multilingual edge of education. Londres: Palgrave Macmillan, 115-137.

\begin{tabular}{|c|c|c|}
\hline & & $\begin{array}{lcc}\text { in } & \text { secondary } & \text { school } \\
\text { (European classes) } & \end{array}$ \\
\hline \multirow[b]{2}{*}{ (2) Regional languages } & $\begin{array}{l}\text { (2a) The same curricula are } \\
\text { used for foreign languages } \\
\text { and regional languages }\end{array}$ & $\begin{array}{l}3 \text { hours a week in primary } \\
\text { and secondary school }\end{array}$ \\
\hline & $\begin{array}{l}\text { (2b) Bilingual education } \\
\text { (dual language education) in } \\
\text { primary and secondary } \\
\text { school }\end{array}$ & $\begin{array}{l}\text { The two languages are used } \\
\text { for teaching on an equal } \\
\text { basis. }\end{array}$ \\
\hline $\begin{array}{l}\text { (3) Migrants' languages } \\
\text { ('ELCO }{ }^{\text {iv }} \text { programme') }\end{array}$ & $\begin{array}{l}\text { Initially taught as a mother } \\
\text { tongue (only for native } \\
\text { speakers). } \\
\text { Currently the curricula tend } \\
\text { to be modelled on the } \\
\text { teaching of foreign languages } \\
\text { (not only aimed at native } \\
\text { speakers). }\end{array}$ & $\begin{array}{l}\text { 1-3 hours a week, outside } \\
\text { school hours, and only if } \\
\text { there are bilateral } \\
\text { conventions between France } \\
\text { and the students' country of } \\
\text { origin. }\end{array}$ \\
\hline
\end{tabular}

Table 2: Educational models for languages other than French

Education in French Guiana operates under the national system apart from the fact that there are no bilateral conventions for migrants' languages and that there is a special model for some of the local languages. As we noted above, around 40 languages are spoken by students in French Guiana, but only some of them are given space in school. Of the local languages, only French Guianese Creole enjoys the status of a regional language. It can be taught according to model 2a (primary and secondary school) or $2 \mathrm{~b}$ (primary school only). The other local languages listed in the Cerquiglini (1999) report (six Amerindian languages, Maroon languages and Hmong) receive limited recognition at the national level by the Ministry of Culture in that they are not totally silenced (their names are included on lists and national websites, and they are recognised as 'languages of France'). However, they are not included in the official educational curricula. One experimental programme has been created for them in French Guiana which targets speakers of 'languages traditionally spoken in the territory', with the help of 'Mother Tongue Facilitators'v. This programme follows a monoliterate transitional model: it exists only in the first years of primary school, children study in their languages from half an hour to five hours a week (depending on the context), but literacy is acquired exclusively through the medium of French. The aim of the programme is mostly to help children learn French; it is officially held that, as an educational official puts it (cited in Alphonse, 2012), 'this programme aims to develop children's competence in their own language in order to have better competence in French afterwards'.

There are no plans for programmes to teach any of the other minority languages. Students who are speakers of these languages are expected to be assimilated, and when questioned, officials answer that they can make use of the foreign language programmes. However, these programmes include only a few of the languages in question, and do not take into account the varieties spoken by the children, such as Brazilian Portuguese or Guyanese English. Many of the languages spoken by the students are not taken into account at all - Haitian Creole and 
Sranan Tongo, for example. ${ }^{\mathrm{vi}}$ For these children, 'pull-out programmes'vii are the main educational model offered, with French being taught as a second language. The children are perceived as 'being limited' (García, 2009b) because they do not speak the school language. It appears that all the educational models currently functioning have the aim of education through monolingualism in French, or, for French Guianese Creole, the development of two monolingualisms (one in French and one in French Guianese Creole). This objective assumes a monolingual model of teaching which forbids interference between languages.

However, the reality on the ground is quite different to the official picture. As a matter of fact, many languages are in contact in all classrooms, whatever the educational model, the students' languages (their multilingual repertoire, including their L1 but also many other languages) and the languages taught at school (French, foreign languages, regional languages). Official discourse and curricula tend to prohibit the use of these languages simultaneously for teaching, regarding them as a barrier to learning the school language. Institutional representatives, acting as representatives of the French state, reinforce the monolingual policy norm, sometimes being even more prohibitive in practice in their instructions regarding the use of languages other than French than the official texts would stipulate. The personal ideologies of these officials towards linguistic assimilation seem to be the key to explaining such attitudes. For example, they often state that there should be a clear (spatial and temporal) separation between the languages, and that only one language should be used at a time in classroom interactions. The various excepts of discourses or programmes presented in example 1 demonstrate this. The excerpts either come from national official curricula and regional projects ( $1 \mathrm{a}$ and $\mathrm{b}$ ) or from national or regional school official interviews (1c and d).

\section{Example 1}

1a [there should be] no use of Creole when the language of the lesson is French and no use of French when the language of the lesson is Creole (bilingual class project).

1b multilingualism is not a handicap or a problem, especially if speakers' languages are clearly identified and if adults have clear attitudes while talking to the child. Teachers represent the French 'pole' of the multilingual situation and they have to stick to it (official curricula, 2006).

1c we have to separate languages - French at school, mother tongues in the family - in order not to damage bilingualisation (national school official).

1d my position is clear (he laughs), they [the teachers] are not paid for that [speaking in the students' languages]! that's it! they are not paid for that! they are paid to teach them [the children] French! (regional school official).

These interesting excerpts show that when minority or local languages are introduced into the classroom the process is still based on binary views of monolingualism or transitional bilingualism, and on traditional notions of languages as static and isolated categories (Cummins, 2005; Creese and Blackledge, 2010). This dominant point of view, which is very widespread among all educational actors, has many consequences for teachers. As a bilingual 
Alby, Sophie \& Isabelle Léglise. (2018). Multilingualism and translanguaging as a resource for teaching and learning in French Guiana. In : P. Van Avermaet, S. Slembrouck, K. Van Gorp, S. Sierens, K. Maryns, (eds.), The multilingual edge of education. Londres: Palgrave Macmillan, 115-137.

class teacher (BCT) puts it in example 2, it impacts on the way he sees the goal of bilingual classes. It also impacts on teachers' practices, as we can see in example 3 in which three teachers (a Mother Tongue Facilitator (MTF), a regular classroom Teacher (T) and a Bilingual Class Teacher (BCT) comment on the necessity of language separation and on the punishments some of them give if children ever speak their own language in the classroom:

\section{Example 2}

BCT the final goal is to facilitate the parallel acquisition of the two languages with a minimum of interference between them.

\section{Example 3}

3a MTF at home it's mundey so with me it's mundey but with [the teacher] it's lun::ndi.

3b $\mathrm{T}$ I punish them [when they speak their languages], because I have told them that they are not allowed to speak their languages in the classroom. As a penalty they have to copy a text in French.

3c BCT We can't put Creole and French in the same places: we have to separate them in order to show the difference between the Creole world and the French world.

Such declarations suggest that teachers largely comply with the monolingual view in line with pressure to do so from school officials who represent their direct hierarchy.

Language separation is the basic principle here (Heller, 1999), as 'the two [or more] languages constitute two [or more] solitudes' (Cummins, 2005). For exampl the bilingual class project (as we saw in 1a) states that there should be a clear separation between French and Guianese Creole both temporally and spatially. From our observations in a wide range of classrooms, we have noticed a clear division between the spaces used for the two languages (see figure 2): Creole is often at the back of the classroom whereas French is (symbolically?) at the front, close to the blackboard, and occupies most of the space.

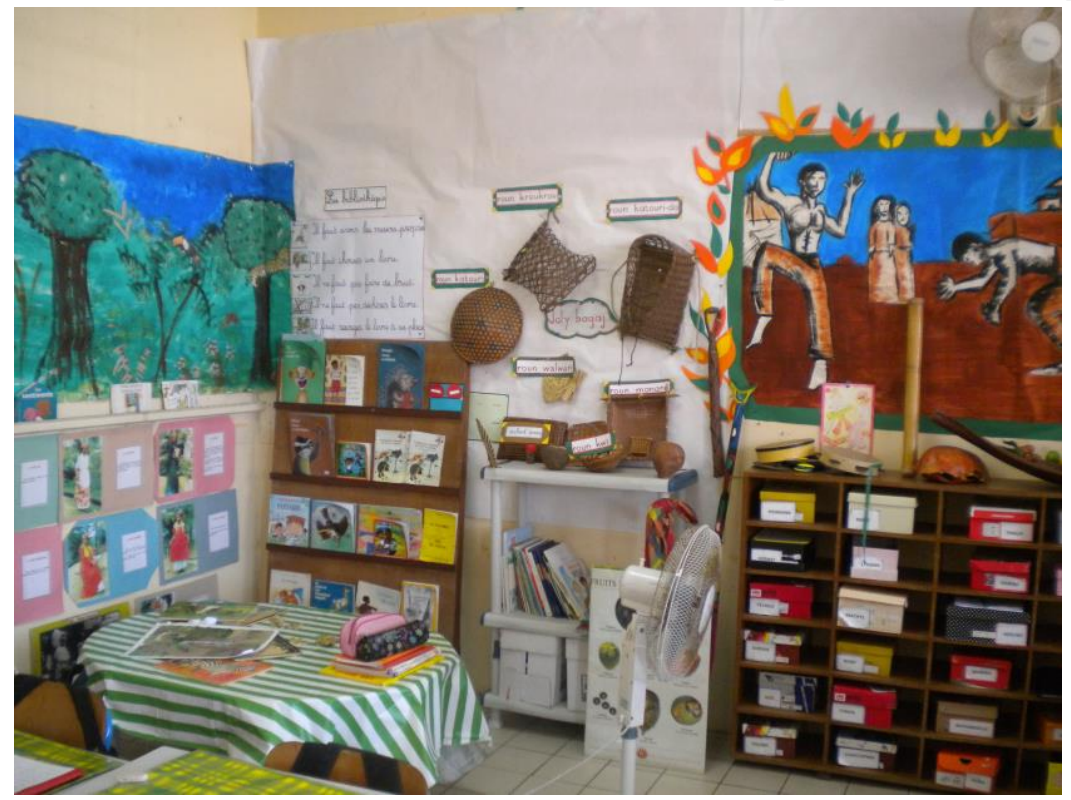


Alby, Sophie \& Isabelle Léglise. (2018). Multilingualism and translanguaging as a resource for teaching and learning in French Guiana. In : P. Van Avermaet, S. Slembrouck, K. Van Gorp, S. Sierens, K. Maryns, (eds.), The multilingual edge of education. Londres: Palgrave Macmillan, 115-137.

Figure 2: The French space and the Creole space in a bilingual classroom

However, this separationist ideology seems to be challenged when confronted with students and the reality of the classroom. The use of the children's multilingual repertoires appears to be a way of teaching and learning in everyday classroom practice. This topic is developed in the next section.

\section{Language spoken in the classroom as an asset for both teaching and learning}

As seen above, official texts do not prohibit the use of languages other than French in the classroom; however, education officials often state that other languages are prohibited when advising and evaluating teachers. On the other hand, ethnographic fieldwork and data from a range of schools in French Guiana show that in everyday interactions in the classroom, the children's languages are often used by the children themselves as a resource for learning, and sometimes also by teachers as a resource for teaching. Teachers do codeswitch, and the children's mother tongues are often used either by the children (in some form of translanguaging) or by the teachers or other participants involved in classroom interactions. Thus 'bilingualism [and multilingualism] is recognized as a potential resource, both cognitively and socially...' (García, 2009a). These data come from various studies, in particular from our own observations and those of our masters students. All data presented below are based on qualitative analysis of classroom interactions (video and audio recordings) aiming to describe the use of pupils' languages in the classroom by teachers and by the children themselves. Examples come from various situations involving multilingual children in different parts of French Guiana: schools on the Maroni river where most children have nenge(e) tongo as a mother tongue (Apatou (Alby, 2008), schools in Papaïchton (Nelson, 2011)), schools on the coastline (Sinnamary (Colletin, 2008), and bilingual classrooms (Pinthière, 2012)).

In the data we see that teachers use different strategies when confronted with the children's multilingualism. Usually this is simply a pragmatic response to the local classroom context (Creese and Blackledge, 2010): the children's languages are used to help them understand instructions or to clarify a lexical item. Strategies differ depending on whether the teacher speaks the children's language, and on the assistance they may have in the classroom. In example 4, the teacher (T) asks a student (S) to translate the instruction about how to throw the ball when playing rugby. This example was recorded in Apatou, with children who have nenge(e) tongo as a mother tongue.

Example 4: (Alby, 2008)

$\mathrm{T}$ voilà (the next child throws the ball in front of him) / NON / non // qu'est-ce qu'on fait quand on a le ballon / on est obligé de courir plus / on n'a pas le droit de faire les passes // donne $>$ (he makes a sign to the child who has the ball) / on n'a pas le droit de faire les passes devant (he makes a sign) // pas le droit / d'accord / dis-lui en taki taki $/$ (so (the next child 
Alby, Sophie \& Isabelle Léglise. (2018). Multilingualism and translanguaging as a resource for teaching and learning in French Guiana. In : P. Van Avermaet, S. Slembrouck, K. Van Gorp, S. Sierens, K. Maryns, (eds.), The multilingual edge of education. Londres: Palgrave Macmillan, 115-137.

throws the ball in front of him) No! no. What do we do when we have the ball? We have to run after it. We are not allowed to pass it. Give it to me! (he makes a sign to the child who has the ball) We are not allowed to pass the ball in front (he makes a sign). Not allowed. Okay. Tell him in Takitaki!)

$\mathrm{S} \quad$ te i de baka ya so / i a mu fiingi en kon ya / i mu luku ya da i kisi iti a ana (when you are behind, like this, you can't throw [the ball] forward, you must look here and when you are here you throw it in his hand)

$\mathrm{T}$ d'accord / que derrière / toujours derrière / donc quand tu as le ballon tu cours un peu plus vite / et tu fais la passe // vous avez compris $\nearrow$ (okay. Only behind. Always behind. So, when you've got the ball you run a little faster, and you pass it. Do you understand?)

Example 5 was recorded during a lesson for children in their first pre-elementary schoolyear, in the little village of Papaïchton on the Maroni river where children have nenge(e) tongo as a mother tongue. Here the teacher (T) gives the student (S) permission to express himself in his mother tongue, but also uses an assistant $\left(\mathrm{A}^{\text {viii }}\right)$ to help the children understand the lesson.

Example 5: (Nelson, 2011)

T qu'est-ce que c'est / (what's this?)

(.)

$\mathrm{T}$ si on ne l'a pas en français donnez-moi en aluku (if you don't know it in French, say it in Aluku)

A saama sabi fa den e kali a sani de / (who knows what is the name of this?)

A o fa dee kali a sani de / (how is it called?)

$\mathrm{S}$ orange (orange)

$\mathrm{T} \quad$ merci c'est bien (well done!)

A e fi yu na sabi fa den e kali e a sani de na faansi, kali en gi mi na aluku tongo (who knows how it is called? If you don't know say it in Aluku) /

$[\ldots]$

T il parle de la couleur c'est pas grave (he's talking about the colour, it doesn't matter)

A pesina (orange)

$\mathrm{T}$ pe::sina ok\ bon/ ben en français ça se dit O/RANGE // (orange, okay. So in French it's ORANGE)

A pesina (orange)

$\mathrm{T}$ on répète / orange / (repeat orange)

$\mathrm{S}$ orange (orange)

T c'est l'orange (it's the orange)

A pesina de kali en orange na fansi (the orange fruit is called orange in French)

In example 6 the teacher $(\mathrm{T})$ uses the children's languages either to translate a question or to ensure that the children (S) have acquired the lexical items that were the aim of the lesson. 
Alby, Sophie \& Isabelle Léglise. (2018). Multilingualism and translanguaging as a resource for teaching and learning in French Guiana. In : P. Van Avermaet, S. Slembrouck, K. Van Gorp, S. Sierens, K. Maryns, (eds.), The multilingual edge of education. Londres: Palgrave Macmillan, 115-137.

Example 6: (Nelson, 2011)

$\mathrm{T}$ vous savez ce qu'elle a mangé C. / [...] (do you know what she has eaten?)

$\mathrm{T} \quad$ vous savez ce qu'elle a mangé /

$\mathrm{S} \quad$ san ye nyang (what did you eat?) [...]

$\mathrm{T} \quad \mathrm{hm} \mathrm{hm} \backslash$ qu'est-ce que tu as mangé C./ (what did you eat?) [...]

$\mathrm{T}$ de la pâte à modeler/ (modeling clay) [...]

$\mathrm{T}$ jaune/(yellow) $[\ldots]$

$\mathrm{T}$ go wasi/ go wasi u mofu/go wasi (go wash your mouth)

$[\ldots]$

$\mathrm{T} \quad \mathrm{ah}: \mathrm{hm} \mathrm{hm} \mathrm{hm/} \mathrm{la} \mathrm{bouche/} \mathrm{montre} \mathrm{moi} \mathrm{la} \mathrm{bouche/} \mathrm{montre/} \mathrm{la} \mathrm{bouche} \mathrm{elle} \mathrm{est} \mathrm{où/} \mathrm{(the}$ mouth, show me the mouth, where is the mouth? - he shows his all body)

$\mathrm{S} \quad$ la bouche (the mouth - he does the same gesture as the teacher showing all the body)

$\mathrm{T} \quad \mathrm{e}$ la bouche de (where is the mouth?)

$\mathrm{S} \quad$ (he shows the teacher's mouth)

T eeye::: c'est bien/ / good! Well done)

These examples are of regular classroom interactions where most children do not speak French, or did not speak it before their first year of school, and live in an environment where French is hardly ever used. In these contexts, teachers are in a way forced to use the children's languages, if they are willing to do so. What catches our attention here is the fact that even in situations where teachers are not obliged to do so, the language separation model is challenged at the level of classroom interaction. Codeswitching happens both in regular classrooms as well as in bilingual classrooms. While codeswitching is forbidden in the bilingual classes programme it often occurs in the bilingual classroom interactions, and teachers admit that it is their usual way of teaching. Some of them even codeswitch when speaking about it (see example 7).

Example 7: bilingual teachers (Pinthière, 2012)

$7 \mathrm{a}$ dans ma classe on retrouve ça souvent / notamment le mélange entre le français et le créole, le français et le brésilien, épi i gen dòt enkò (in my classroom we see that a lot, especially mixing between French and Creole, French and Brazilian Portuguese, and some more)

$7 \mathrm{~b}$ comme par exemple dans ma classe bilingue, on va mélanger français ké kréyòl (for example, in my classroom we mix French with Creole)

7c épi bon a pa yé sèlman ka itlisé yé lang nou menm osi nou ka itlisé nou lang annan tout okazion (and also well they (the children) are not the only ones to use their languages, we do as well, in all situations)

$7 \mathrm{~d} \quad$ mo ka itlisé kréyòl tou léjou mo menm ki kour fransè ki kour kréyòl (I use Creole every day, either in the Creole lesson or in the French lesson)

Recordings of interactions in classrooms confirm these statements, as shown in example 8 which illustrates a bilingual mode of discourse between Guianese Creole and French used by 
the teacher in everyday classroom interaction. The fact that this form of bilingual education involves only one teacher for the two languages (whereas in other cases each language has its teacher) seems to facilitate their recourse to translanguaging:

Example 8: in a bilingual classroom (Pinthière, 2012)

$\mathrm{T}$ jodla nou ké continwè asou lèr-a, mais nous allons voir les heures de l'après-midi c'est-à-dire kouman yé ka di lèr aprémidi - ya ké kouman zót ka plasé yé a sou orlaoj-a. Épi nou té ja wé yé mo ka èspéré ki zót pa bliyé (today we will work on the afternoon hours, but we will see the afternoon hours that is to say how do we name the afternoon hours, how do we place them on the clock. We have already had a lesson on it, so I hope you didn't forget about it)

$\mathrm{T} \quad$ est ce que vous pouvez lever zòt orlòj! (can you hold up your clock!)

$\mathrm{T}$ ès zòt konprann? Est-ce que vous comprenez? Si vous ne comprenez pas il faut me le dire (do you understand? Do you understand? If you don't understand you have to tell me)

$\mathrm{T}$ atò mo ka raplé zòt ki sèz èr a katrèr de l'après-midi, il faut que vous mettiez la grande aiguille sur le douze et la petite sur le six. (So I remind you that 16h is four in the afternoon, you have to put the big hand on twelve and the small one on six)

We tried to identify incidents when translanguaging was mostly used by children. In fact, work in small groups seems to increase the recourse to translanguaging among students, especially when these groups are multilingual, as in examples 9, 10 and 11 below. The students (S1, S2, S3 and S4) in this secondary school have four languages in their multilingual repertoire among which they share French and French Guianese Creole. We see here how they use those two languages as lingua francas in order to perform the tasks they are asked to do in sports (in example 9, the students have to perform five figures, and the fastest group wins), in mathematics (example 10, discussion of a maths problem) and in French grammar (in example 11 they have to produce sentences with adjectives).

Example 9: sport classes in secondary school (Colletin, 2008)

S1 S2 arété! (stop it S2!)

$\mathrm{T} \quad$ soit vous vous tenez comme ça soit /// (either you make this position or...)

S1 croisé to lanmain osi (cross your hand as well)

$\mathrm{T}$ non mais applique-toi faut quand même que tu aies un appui (you have to concentrate on it, you need to lean on something)

S1 S3 vini la mété to pié a con sa pou mandam hein man (S3 put your foot here, it has to be done like this, hey, $\underline{\operatorname{man}}$ )

S2 non pa ka monté bicyclette en arrière (no don't climb the bicycle by the back)

T allez! (go on!)

S3 en nou mété nou (let's set up)

S4 a con sa man (it's like this, $\underline{\operatorname{man}}$ )

$\mathrm{S} 1$ ouais con sa man (yes like this $\underline{\mathrm{man}}$ )

$\mathrm{T}$ lorsque vous mettez un genou (when you put a knee) 
Alby, Sophie \& Isabelle Léglise. (2018). Multilingualism and translanguaging as a resource for teaching and learning in French Guiana. In : P. Van Avermaet, S. Slembrouck, K. Van Gorp, S. Sierens, K. Maryns, (eds.), The multilingual edge of education. Londres: Palgrave Macmillan, 115-137.

S1 entend a pou to S3 pié aw passé là (listen, it's for you S3, your foot has to be here)

Example 10: among adolescents, maths lesson in secondary school (Colletin, 2008)

S4 kombyen sa ka bay? (what's the result?)

S3 sa mo mo trouvé disét (I found 17)

S4 a sa mo té mété kat a pou sa man (that's why I wrote 4 , man)

S1 a con sa man gadé (look, you have to do it this way, $\underline{\text { man })}$

S3 mo mo pa fé kon sa mo météy kon sa (I didn't do it like this, I did it like that)

S1 a kenz man a pa disét (it's 15, man not 17)

Example 11: among adolescents, French grammar, in secondary school (Colletin, 2008)

S4 koté nou té yé anko /// la poubelle /// la moto non la poubelle de ma belle-mère en ka ékri-l (Where were we again? the dustbin. The motorbike no my stepmother's dustbin, we have to write it).

S3 hm hm

S4 la poubelle de ma belle-mère est sale /// sale // to gen konbyen mo (my stepmother's dustbin is dirty. Dirty. How many words have you got)

S1 un deux trois quatre cinq (one, two, three, four, five)

S4 cinq simplement mo gen sis /// la maison de ma fiancée est belle (only five, I've got six. My fiancee's house is beautiful)

S3 ki sa? (What?)

S4 la maison de ma fiancée est belle (My fiancee's house is beautiful).

S3 an nou mété de mon fiancé (we should put 'my fiancé's'.)

S4 awa i pa ka alé /// to ja mété bel en nou mété splendide mo pas sav koumann sa ka ekri /// la moto de l'agent de police est // oh nou preske/presque fini (No, it's not working. You've already written beautiful, we should put gorgeous, I don't know how to write it. The police officer's motorbike is ... Oh! We're almost done.)

A comparison of this group with others who have 'chosen' to use only French shows that this group achieved the task more easily, especially because they communicate a lot more, which implies that their multilingualism is a resource for learning (Colletin, 2008).

Even if multilingualism is not officially seen as an asset for teaching and learning, we see that students and sometimes teachers engage daily in translanguaging. They use their multilingual resources to improve communication, and also to improve their learning in all school subjects. But there are some variations in the use of the childrens' languages depending on the programme. In general education classrooms, where children are already speaking French, their multilingualism is not taken into account whereas the bilingual classrooms seen in examples 7 and 8 (one teacher speaking two languages) and small groups (examples 9 to 11) seem to be facilitating factors for using all the resources of students' repertoires. 
Alby, Sophie \& Isabelle Léglise. (2018). Multilingualism and translanguaging as a resource for teaching and learning in French Guiana. In : P. Van Avermaet, S. Slembrouck, K. Van Gorp, S. Sierens, K. Maryns, (eds.), The multilingual edge of education. Londres: Palgrave Macmillan, 115-137.

In bilingual classes, translanguaging seems to be a natural way to teach and to learn, even if it is officially prohibited: 'students and teachers accept and adopt translanguaging practices that enable them to function effectively, and educate and become educated' (García, 2009b). In other classes, language choice largely depends on the teachers, on their skills in the languages involved, on their attitudes and also how much they can rely on the assistance of the speakers of other languages. In any case, again, translanguaging (either by children or by teachers) does frequently occur. The next step should be to acknowledge the fact that translanguaging is a teaching/learning model in all schools and classrooms.

\section{Conclusion}

Language ideologies which promotes monolingualism, language separation and linguistic assimilation all exert a powerful influence on education in French Guiana on different levels. In particular, on the meso-level, school officials and regional directors who act as representatives of the French state are sometimes in practice even more prohibitive regarding the use of languages other than French than what is stipulated in the official texts. In any case, and even in bilingual programmes, these education officials recommend language separation, and they appear to be key mediators in the reproduction of state policies and ideologies on the classroom level.

On the micro-level, we noticed that these ideologies have a strong influence but we also saw micro movements towards change. First, while the prohibition of languages other than French is still noticeable in the overt declarations of (some) teachers, children's languages do take de facto a space in the classroom. Second, even in bilingual programmes, the ideology of language separation is still very present either in teachers' discourse or in their own practices. Third, some teachers and a majority of students do express a certain degree of agency in 'doing' codeswitching, as a form of resilience to linguistic assimilation in action and language separation. Children draw on their entire multilingual repertoire in some situations, regardless of whether they are allowed to do so or if they speak the school language. They engage in translanguaging whenever possible. In particular, this seems to happen much more when they are emergent bilinguals (García, 2009b; Alby and Léglise, forthcoming) or when they are working together in small groups. Bilingual programmes and work in small groups are facilitating factors for using all the resources of students' repertoires.

We feel that multilingual pedagogies (García and Flores, 2015) seem to be a solution that ought to be tried in French Guiana, since multilingual repertoires are common both outside and inside the classroom. Adopting multilingual pedagogies would acknowledge the current language practices of most students and transform monolingual education and bilingual programmes into programmes drawing on various semiotic and linguistic resources and building on the multilingualism of the students. However, in order to implement multilingual pedagogies, more research needs to be done on what happens in the classroom in order to prove the positive effects of teachers' multilingual practices. Teacher training and raising the awareness of education officials constitute two sides of a common work in progress. Starting 
Alby, Sophie \& Isabelle Léglise. (2018). Multilingualism and translanguaging as a resource for teaching and learning in French Guiana. In : P. Van Avermaet, S. Slembrouck, K. Van Gorp, S. Sierens, K. Maryns, (eds.), The multilingual edge of education. Londres: Palgrave Macmillan, 115-137.

from the everyday codeswitching practices of successful teachers could be a way of changing education policy from a top-down to a bottom-up model.

\section{References}

Alby, S. (2008). "Faire faire" et "faire mieux dire" à des élèves en contexte allophone. Pratiques des enseignants dans une école de l'Ouest guyanais. in Recherches et Applications Le Français dans le monde, 44, pp. 98-110.

Alby, S., and Launey, M. (2007). "Former des enseignants dans un contexte plurilingue et pluriculturel". In Pratiques et représentations linguistiques en Guyane : regards croisés, I. Léglise, and B. Migge, eds. (Paris: IRD Editions), pp. 317-348.

Alby, S., and Léglise, I. (2005). "L’enseignement en Guyane et les langues régionales, réflexions sociolinguistiques et didactiques." Marges Linguistiques 10, pp. 245-61.

Alby, S., and Léglise, I. (2014a). "Politiques linguistiques éducatives en Guyane. Quels droits linguistiques pour les élèves allophones ?" L'école plurilingue en outre-mer : Apprendre plusieurs langues, plusieurs langues pour apprendre, I. Nocus, J. Vernaudon, and M. Paia, eds. (Rennes : Presses Universitaires de Rennes), pp. 271-296.

Alby, S., and Léglise, I. (2014b). "Pratiques et attitudes linguistiques des enseignants. La gestion du plurilinguisme à l'école en Guyane." In L'école plurilingue en outre-mer :

Apprendre plusieurs langues, plusieurs langues pour apprendre, I. Nocus, J. Vernaudon, and M. Paia, eds., (Rennes: Presses Universitaires de Rennes), pp. 245-67.

Alby, S., and Léglise, I. (2016). " L'éducation bilingue dans le contexte multilingue guyanais : dispositifs cloisonnants et pratiques pédagogiques innovantes ". In L'éducation bilingue en France :politiques linguistiques, modèles et pratiques, C. Hélot, J. Erfurt (eds.), Paris : Lambert Lucas, 66-86

Alphonse, A. (2012). Discours officiels sur le plurilinguisme à l'école en Guyane. Master 2 Thesis. Université des Antilles et de la Guyane.

Colletin, D. (2008). Contacts de langues en Guyane française : interactions et choix de langues en $3 e$ et 4 e SEGPA à Sinnamary. Master 2 Thesis. Université des Antilles et de la Guyane.

Conseil de l'Europe (1992). European Charter for Regional or Minority Languages. http://conventions.coe.int/Treaty/FR/Treaties/html/148.htm. Last accessed: 19/03/15.

Creese, A., and Blackledge, A. (2010). "Translanguaging in the Bilingual Classroom: A Pedagogy for Learning and Teaching?" Modern Language Journal, 94, 103-115.

Cummins, J. (2005). "A proposal for action: Strategies for recognizing heritage language competence as a learning resource within the mainstream classroom". Mod. Lang. J. 585-592. 
Alby, Sophie \& Isabelle Léglise. (2018). Multilingualism and translanguaging as a resource for teaching and learning in French Guiana. In : P. Van Avermaet, S. Slembrouck, K. Van Gorp, S. Sierens, K. Maryns, (eds.), The multilingual edge of education. Londres: Palgrave Macmillan, 115-137.

García, O. (2009a). "Education, multilingualism and translanguaging in the 21st century". In Multilingual Education for Social Justice: Globalising the Local, A. Mohanty, M. Panda, R. Philipson, and T. Skutnabb-Kangas, eds. (New Delhi), pp. 128-145.

García, O. (2009b). "Emergent Bilinguals and TESOL: What's in a Name?" Tesol Quarterly, 43 (2), 322-326.

García, O., and Kleifgen, J.A. (2011). "Bilingualism for equity and excellence in minority education: the United States". In Equity and Excellence in Education, K. Van den Branden, P. Van Avermaet, and M. Van Houtte, eds. (New York: Routledge), pp. 166-189.

García, O. and Flores, N (2015) "Multilingual pedagogies", in The Toutledge Handbook of Multilingualism, M. Martin-Jones, A. Blackledge, A. Creese, eds. (London: Routledge), pp. 232-246.

Goury, L., Launey, M., Queixalós, F., and Renault-Lescure, O. (2000). "Des médiateurs bilingues en Guyane française.” Revue française de linguistique appliquée V-1: 43-60.

Grenand, F. (1982). "Le problème de l'enseignement du français en milieu tribal en Guyane". CENADDOM 19-26.

Heller, M. (1999). Linguistic minorities and modernity: A sociolinguistic ethnography (London: Longman).

Hurault, J.-F. (1972). Français et Indiens de Guyane (Paris: 10/18).

Launey, M. (1999). "Les langues de Guyane : des langues régionales pas comme les autres ?" In Langues et Cultures Régionales de France. Etat Des Lieux, Enseignement, Politiques, C. Clairis, D. Costaouec, and J.-B. Coyos, eds. (Paris: L'Harmattan), pp. 141-159.

Léglise, I. (2007). "Des langues, des domaines, des régions. Pratiques, variations, attitudes linguistiques en Guyane". In Pratiques et Représentations Linguistiques En Guyane : Regards Croisés, I. Léglise, and B. Migge, eds. (Paris: IRD Editions), pp. 13-30.

Léglise, I. (2013). Multilinguisme, variation, contact. Des pratiques langagières sur le terrain à l'analyse de corpus hétérogènes. HDR. INALCO.

Léglise, I., and Puren, L. (2005). "Usages et représentations linguistiques en milieu scolaire guyanais". Univers Créoles Ecoles Ultramarines 67-90.

Migge, B., and Léglise, I. (2010). "Integrating local languages and cultures into the education system of French Guiana : a discussion of current programs and initiatives". In Creoles in Education : An Appraisal of Current Programs and Projects, B. Migge, A. Bartens, and I. Léglise, eds. (Amsterdam: John Benjamins), pp. 107-132.

Migge, Bettina, and Isabelle Léglise. (2013). Exploring Language in a Multilingual Context: Variation, Interaction and Ideology in Language Documentation. (Cambridge: Cambridge University Press). 
Alby, Sophie \& Isabelle Léglise. (2018). Multilingualism and translanguaging as a resource for teaching and learning in French Guiana. In : P. Van Avermaet, S. Slembrouck, K. Van Gorp, S. Sierens, K. Maryns, (eds.), The multilingual edge of education. Londres: Palgrave Macmillan, 115-137.

Nelson, L. (2011). Enjeux sociodidactiques d'un enseignement bi-plurilingue précoce en contexte éducatif guyanais : analyse interactionnelle d'une expérience pédagogique dans une classe. Paper presented at the Conference "Les contextes éducatifs plurilingues et francophones hors de la France continentale : entre héritage et innovation". June 6-7, Nantes

Pau-Langevin, G. (2014). "Haute qualité éducative" : la Guyane de la réussite. Huffington Post.

Pinthière, E. (2012). L'enseignement du créole en milieu scolaire. Les alternances codiques dans les classes bilingues. Master 2 Thesis. Université des Antilles et de la Guyane.

\footnotetext{
${ }^{i}$ We would like to thank two anonymous reviewers for their valuable comments and suggestions to improve this paper.

ii 'School officials' refers to the officials in charge of teachers in primary school. They are not school administrators or principals but primary school inspectors, regional directors of education etc.

iii See www.conseil-constitutionnel.fr (Constitution, art.2)

iv Teaching of origin languages and cultures.

${ }^{\vee}$ Programme Intervenants en Langues Maternelles (ILM). See Goury et al (2000) or Migge and Léglise (2010) for a description of the programme.

${ }^{\text {vi }}$ A few exceptions do exist: Portuguese has been included in the ILM programme, Dutch is taught in the western part of French Guiana due to the proximity with Suriname.

vii The student is taken out of the regular classroom 50 per cent of the time the first year, 25 per cent the second year, and is then supposed to be full time in the regular classroom.

viii Some assistants do help in classrooms for children aged from three to five.
} 